\title{
A NEW WAY OF INVESTING ON THE AGRICULTURAL REAL ESTATE MARKET IN POLAND
}

\author{
Jarosław Szreder, PhD \\ Faculty of Management \\ Hanseatic Higher School of Management in Stupsk \\ e-mail:jszreder@apion.pl \\ Piotr Walentynowicz, PhD \\ Faculty of Management \\ University of Gdansk \\ e-mail:p.walentynowicz@wzr.ug.edu.pl
}

\begin{abstract}
When compared to other segments of the market, the agricultural real estate market is a completely different world. While there have been possibilities to observe price corrections over the recent years of the economic crisis, e.g., on the housing market in big cities, on the market of holiday apartments or building plots, the agricultural real estate market remains stable in relation to prices. The average transactional prices of agricultural real properties are gradually growing, and the number of purchase transactions is continuously increasing. Based to the above mentioned trends, the author of the present paper put forward the thesis that investing in agricultural real properties is economically justified during times of economic crisis. One of the best forms of capital investment is that of a limited joint-stock company (S.K.A.).
\end{abstract}

Key words: agricultural real estate, investing in real estate.

JEL Classification: G11.

Citation: Szreder J., Walentynowicz P., 2014, A new way of investing on an agricultural real estate market in Poland, Real Estate Management and Valuation, vol. 22, no. 1, pp. 5-12.

DOI: $10.2478 /$ remav-2014-0001.

\section{Introduction}

Investments on the real estate market are one of the many ways ${ }^{1}$ of investing capital. In a classification approach, direct investments in real properties (among others: land, buildings and constructions, service or manufacturing objects), are material investments (HENZEL, 2004). Purchasing shares in funds investing on the real estate market (in the form of, e.g., investment certificates or share units) and purchasing shares or interests of partnerships in which the majority of assets are composed of real properties are examples of financial investments or, more precisely speaking, share instruments of the real property market (ADAMSKA, FIERLA 2010).

The subject of research, the results of which are presented in the present article, is the market of agricultural real estate in Poland, especially in the context of opportunities, possibilities and risks of undertaking new investments.

1 E.g., purchasing shares or interests of companies, government bonds and those emitted by enterprises, share units in investment funds, or shares in so-called alternative investments (precious metals, works of art, wines, etc.). 
The paper presents the past and current situation on the agricultural real estate market in Poland. Further parts of the article demonstrate the advantages and disadvantages of the classic ways of investing on this market. On the basis of the conducted research and the authors' own professional experience, an attempt was made to evaluate the discussed possibilities of investing. However, the main aim of the article is to present the concept of an alternative way of investing in agricultural real properties. This form calls for the participation of investors in a limited joint-stock company. In such a structure, investors play the role of shareholders, with specific rights arising from the Commercial Companies Code (CCC) and the formal documentation of the partnership. A specialized and experienced company on the real estate market is a general partner, managing all affairs of the partnership. Analyses carried out within this study allowed for conclusions regarding the legitimateness and sensibility of this means of investing on the agricultural real estate market in Poland to be drawn.

\section{Present and future situation on the agricultural real estate market}

Poland is the fourth country in the EU, after France, Spain and Germany, in regards to the quantity of agricultural land. The surface area of the cultivated land is around $19 \mathrm{mln}$ hectares $-75 \%$ of which are arable lands, $20 \%$ - green areas such as meadows and pastures, with the remaining part consisting of other cultivated lands. Farmland covers $58 \%$ of the surface of the whole country, as compared to the $40 \%$ average for all EU member states (WWW.EPP.EUROSTAT.EC.EUROPA.EU. 02.02.201). What is more, Polish agriculture is characterized by a significant fragmentation of farms. The average surface of a farm in Poland is only 8.44 ha, as opposed to approximately 18 ha in the EU (WWW.ANR.GOV.PL. 02.02.2013).

The market of arable land in Poland may be divided into two basic segments: the first one concerns trading privately-owned land, with the second regarding state-owned plots, where the main role is played by the Agricultural Property Agency (APA). The later segment sells or leases real properties belonging to the State Treasury. At the beginning of the transformation of this country's political system, i.e., in the early 1990s, this organization possessed $4.7 \mathrm{mln}$ ha of land. At the end of 2011, it owned $1.954 \mathrm{mln}$ ha, out of which 1.465 ha (i.e., around 75\%) was in leasing (WWW.ANR.GOV.PL. 02.02.2013). During the recent 20 years, a continuous growth of transactional prices of agricultural real properties has been observed. What is more, from the moment Poland joined the EU in 2004, agricultural land in Poland has become four times more expensive. Figure 1 presents the average prices of agricultural land during the recent 20 years.

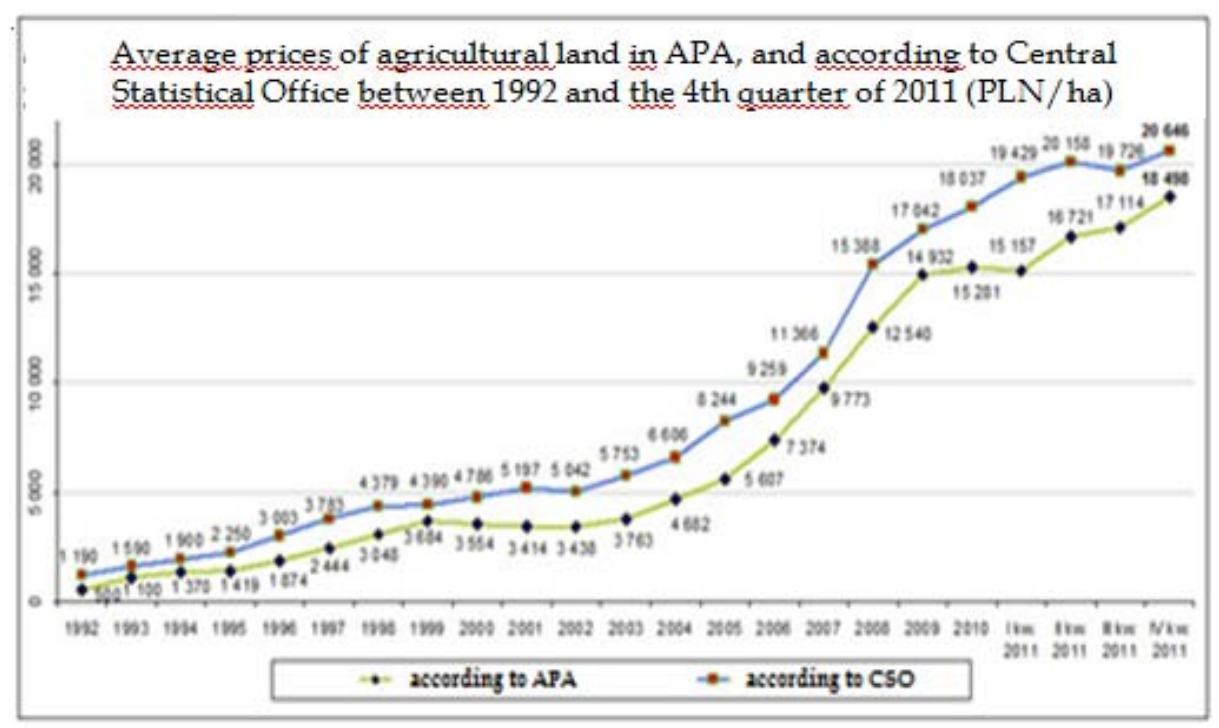

Fig. 1. Average prices of agricultural land according to the APA and CSO between 1992 and 2011, Source: Internet, www.egospodarka.pl.

Apart from transactions conducted by the APA, prices of land according to the CSO also account for private trading. In addition to this, there is a significant spatial differentiation of prices on the agricultural land market in Poland, which has been presented in Figure 2. 


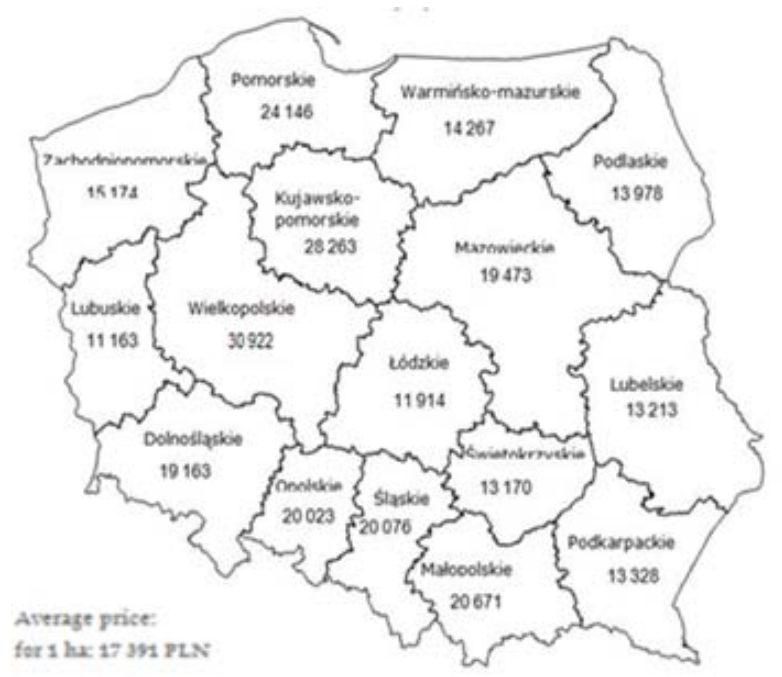

Fig. 2. Average prices of agricultural land in 2012, with division into voivodeships, Source: Internet, www.anr.gov.pl.

The highest prices are observed in the Wielkopolskie, Kujawsko-Pomorskie and Pomorskie voivodeships. The lowest ones are present in the eastern regions of the country, as well as in the Lubuskie and Zachodniopomorskie voivodeships. Apart from the increase of average prices, a growing number of transactions has also been observed recently. In 2011, the APA sold 125,000 ha of land, i.e., 30\% more than when compared to 2010. The initial prognosis for 2012 shows the sales of agricultural land to be at a level similar to that of 2011. According to experts in the field and bank analysts, such a high number of transactions and an increasing level of transactional prices is the result of demand generated by farmers. It is influenced by factors like: subsidized loans for purchasing land, the possibility to pay for land in installments, an increase in the profitability of agricultural production, and the opportunity to take advantage of direct subsidies from the EU (WI INWESTYCJE ROLNE, FIZ, MEMORANDUM).



Fig. 3. Average prices of agricultural land in chosen member states of the EU (for 1 ha), Source: Internet, www.inwestycyjerolne.pl, Memorandum 2012. 
It seems that the most significant factors that may influence the market of agricultural land in Poland in the following years are: a limited supply of agricultural lands (supplies of the APA are continuously decreasing and there is an accumulation of land in the hands of big producers), the steady increase of food prices in Poland and throughout the world, and the growing significance of land when it comes to the production of electrical energy (i.a., growing energy crops, emerging photovoltaic farms, the development of wind energetics). The constant development of urbanized areas is also important here, as well as the opening of the Polish agricultural land market to foreign investors planned to take place in 2016. It also needs to be emphasized that despite the continuous growth of average agricultural land prices in Poland during the recent 20 years, they are still the lowest in the entire EU. This fact has been presented in figure 3.

\section{Ways of investing in the agricultural real property market}

Similarly to other segments of the real estate market, the agricultural property market is characterized by market rights. Anywhere where there is a possibility of earning money, investors wanting to make a profit start to appear. However, investing on these markets is not as simple and clear as, for example, in the case of the housing market or that of construction plots. Among the simplest forms of investing, we should also list: purchasing land by individual investors, purchasing land in joint ownership with other natural persons, and specialized investment funds like REIT (CHAN AND OTHERS, 2003). All of the above mentioned forms have both advantages and disadvantages, which are presented in the following table.

Table 1

Advantages and disadvantages of different forms of investing in real properties

\section{Purchasing agricultural land in sole ownership}

\section{Advantages:}

- independent investment decision,

- no partners,

- a possibility to run the farm on one's own or to lease it out,

- proportionally higher profitability of the investment than in the other forms.

\section{Disadvantages:}

- necessity to raise significant capital,

- necessity to search for real estate that can be purchased on one's own,

- checking the legal status and factual condition of the property on one's own,

- checking the price levels of similar land in microlocations and examining the locations on one's own (logistics from the perspective of running an agricultural business or possibly leasing the land),

- organizing the agricultural business on one's own,

- low liquidity risk,

- preparing applications for subsidies from the ARMA (Agency for Restructuring and

Modernization of Agriculture),

- no diversification of the investment,

- higher economic risk.

\section{Purchasing agricultural land in joint ownership with other natural persons}

\section{Advantages:}

- greater diversification of the investment in comparison to the first variant,

- possible lower capital requirements,

- lower economic risk than in the first variant.

\section{Disadvantages:}

Similar to those of the first variants, but divided between the partners, and additionally:

- the necessity of agreeing on decisions with partners,

- gathering partners with similar investment interest in terms of time and space,

- low liquidity risk,

- danger of conflicts between partners. 


\section{Specialized investment funds investing in real estate}

\section{Advantages:}

- no necessity of having specialized knowledge of the agricultural market and agricultural business, - possibility to amortize or move investment certificates,

- no income tax from Investment Fund

Companies,

- lowest investment risk out of the above mentioned cases.

\section{Disadvantages:}

- high costs of the fund operation, which need to be covered by investors (e.g., evaluating certificates),

- necessity of paying a commission when purchasing investment certificates even when a fund is losing money,

- necessity of covering a distribution charge for making purchases, as well as permanent and changeable payments,

- virtually no control over the operation of the fund,

- lower profitability than in the first and second forms of investments.

Source: own work.

As presented in the above table, the different solutions have their weak as well as strong points. When wanting to invest in the agricultural property market on one's own, the investor needs to be aware of the significant costs connected with the preparation of the investment and the large amount of time it consumes. Joint ownership, on the other hand, may be risky if decisions regarding further actions can't be reached with the partners. This situation especially applies to "withdrawing from an investment" (i.e., selling a real property), when the consent of all partners is necessary. An alternative solution is the contractual or court abolishment of joint ownership. In the case of investment funds, there is a need to be aware of the high costs of such investments. When taking the above factors into consideration, a form of a limited joint stock company ${ }^{2}$ seems to be a promising answer for investors making investments on the agricultural property market.

\section{Alternative ways of investing in agricultural properties}

In a proposed business model, the role of a general partner is played by a professional subject who manages the partnership's affairs and is responsible for the business. Shareholders are natural or legal persons wishing to invest in agricultural real estate with the intention of protecting capital, diversifying their investment portfolio, or obtaining a satisfactory rate of return.

The assumptions of the new business model anticipate the organization of a farm within a given area through taking the following actions: establishing a partnership (S.K.A.), raising capital by the company by emitting shares, purchasing agricultural land, running the farm, i.e., growing crops and conducting other activities which optimize the profitability of the agricultural production. This model also assumes the selling of the partnership's property or an organized part of the enterprise the moment it becomes optimal for the partnership. The general partner is liable for the current and strategic results of the company. Operating earnings are obtained by the company from its operational activity - agriculture, and from direct subsidies for agriculture from the ARMA ${ }^{3}$. The consolidation of separate real properties (large-area farms are more profitable than fragmented ones) and an increase in property value influenced by exogenous factors are also sources of market value growth of the partnership's real property.

There is a series of arguments which support applying a form of a limited joint-stock company for the purpose of realizing investments in agricultural properties. The most significant of these include: the transparency of the partnership and shareholders' rights determined in the Commercial

\footnotetext{
2 According to Art. 125 of the Act from 15th September 2000, Commercial Companies Code (CCC), a limited jointstock company is a partnership, whose aim is to operate a business enterprise under its own company, where at least one partner is liable with no limitations (general partner) for the obligations of the company towards creditors, and at least one partner is a shareholder. The shareholder is not liable for the partnership's obligations (Art. 135, CCC).

3 Simple rates of return are estimated at the following levels: from agricultural production $2-6 \%$ annually, from direct subsidies from the ARMA 5-10\% annually, from selling real estate $20 \%$ of annual gain.
} 
Companies Code, the fact that affairs are managed by a competent and specialized entity (general partner), and the possibility to diversify the investment of a shareholder who "automatically" becomes a co-owner of the partnership when acquiring its shares and, at the same time, indirectly becomes a co-owner of all real properties belonging to that partnership 4 . It is assumed that the general partner, i.e., organ managing all the partnership's affairs, is specialized and experienced in realizing undertakings on the real estate market and in operating the company's agricultural enterprise in the form of a limited liability partnership. The tasks of the company include, i.a., searching for real properties with a growth potential which are to become the subject of an investment, analyzing the legal status of an investment, examining the physical condition of land being purchased, examining the localization of the investment from the perspective of operating an agricultural enterprise, researching levels of transactional prices of agricultural real properties within the closest surroundings, conducting analyses of the economic legitimacy of the investment, finding investors, conducting the transaction and managing the investment until the real property is sold at a time that is optimal for the shareholders. Running a farm within the scope of the possessed agricultural real properties may be organized by the company itself or may be commissioned to third parties in the form of outsourcing. This model assumes the second form of running a farm.

Another argument that is important to an investor is the aspect of simple formalities connected with the acquirement and selling of shares. The acquisition of shares is a one-sided notary action, conducted in a notary office that is convenient for an investor. Shares emitted by the partnership are subject to trading according to the shareholder's decisions. This means that a company does not introduce any limitations when it comes to the disposal of shares. Thanks to this, investors are able to sell the shares and, at the same time, "withdraw from the investment" at any given time, determining the conditions of the withdrawal themselves. The high liquidity of the company's shares, contrary to real property or shares in joint real property, seems to be a significant argument in favor of such an option for the investors. The construction of the partnership assumes a minimal share of a single investor at the level of 10,000 PLN, which is equivalent to the purchase of about 0.5 ha of agricultural land according to the average price of agricultural real estate in 2012. Therefore, it appears that such a partnership may be a great solution to many people with limited financial abilities which prevent them from making independent investments on the real estate market.

The attractiveness of a limited joint-stock company from the perspective of taxation is also of great significance to investors. According to the current regulations of tax law, in the case of a limited jointstock company, a single taxation of income at the level of the partners applies. This means that, first of all, the company itself is not burdened with an income tax ${ }^{5}$. Secondly, the partners' tax duty arises at the moment a dividend is paid by the partnership or the partnership's shares are sold. An alternative way for the company to pay profits to its shareholders is the redemption of shares through purchasing them by the partnership, according to Art. 359, CCC (KOLIBSKI M. 2012).

Nowadays, the security of investors has taken on much importance. The construction of an undertaking assumes a series of solutions that are advantageous for the investors. Key decisions considering the functioning of the company and division of profits are regulated by the company's statute. Additional protection for the investors is provided by the terms and conditions of the good practices of a general partner. The most important provisions of this document clearly determine the conditions and amount of the general partner's remuneration. Remuneration will be paid only if the partnership makes a profit (a so called success fee). An additional guarantee for the investors is the fact that investors will not pay directly to the partnership's account for acquiring shares, but to a special bank custody account. The agreement implies that a bank is to make a money transfer for the purchase of real estate to the account of the seller only when specific requirements determined in the custody agreement are met (e.g., the purchase price does not exceed 20,000 PLN for 1 ha). The custody

\footnotetext{
4 This means that, for example, instead of having $100 \%$ shares in one investment, an investor has $10 \%$ of shares in 10 different localizations.

5 According to the statement of the Ministry of Finances, the government intended to introduce a taxation on limited joint-stock companies starting $1^{\text {st }}$ January 2013. However, these changes did not enter into force, as the government did not hand the amendment project to the Seym within the time frame that would allow it to enter into force in 2013. Due to the significant doubts arising as a result of the short period separating the passing of these changes and the date that they are planned to enter into force (so called: vacatio legis), it seems plausible that the government will attempt to enforce the amendment from 2014. Source: Internet, www.deloitte.com, $5^{\text {th }}$ February 2013.
} 
agreement, partnership's status and terms and conditions of good practices of the general partner are made available to the investors before making final investment decisions. The advantages and disadvantages of this form of investing on the agricultural real property market have been presented in Table 2.

On the basis of the presented information, we can make a conclusion that the proposed form of investments is more beneficial than other forms of investing on the agricultural real property market. It may also become an attractive form of allocating capital, especially for passive investors.

Table 2

Advantages and disadvantages of investing in agricultural real properties in the form of a limited joint-stock company

\begin{tabular}{|l|l|}
\hline Advantages: & $\begin{array}{l}\text { Disadvantages: } \\
\text { - market risk, }\end{array}$ \\
- potentially attractive return rate, & - limited possibility to control how the \\
- easy way of entering into a partnership & partnership operates, \\
- liquidity of the acquired assets, & - lower profitability than in the case of an \\
- possibility to diversify the investment & independent business enterprise on the \\
- no conflicts among partners, & agricultural real property market. \\
- investment is managed by a professional, & \\
- joint liability for the result of the investment of the & \\
managing company (which is not present in, e.g., investment & \\
funds). & \\
\hline
\end{tabular}

Source: own work.

\section{Summary and conclusions}

The market analyses presented in this article, and trends observed at the end of 2012 and at the beginning of 2013, as well as the behaviors of investors, confirm the thesis that investing on the agricultural real property market during an economic crisis may be economically justified. The agricultural land market is perceived by some investors as a relatively safe form of investing a surplus of capital, which may result in a significant return rate over a longer period of time (at the level of a dozen or so percent per year ${ }^{6}$. The authors realize that the briefly presented alternative model of investments on the agricultural real estate market is not free of disadvantages, which had been extensively described in literature on the subject (HENZEL 2009). Nevertheless, it may be a beneficial solution, especially for those investors that do not have enough capital to be able to effectively invest in the agricultural real property market. What is more, investing in the form of a limited joint-stock company may also turn out to be an effective form of joint investments in other segments of the real estate market.

\section{References}

ADAMSKA A., FIERLA A. 2010, Inwestowanie, wybrane zagadnienia (Investing, chosen notions), Publishing house: WYDAWNICTWO SZKOŁy GŁÓWNEJ HANDLOWEJ, Warsaw, p. 156.

CHAN S.H., ERICKSON J., WANG K. 2003, Real Estate Investment Trusts, OXFORd UnIVERSITY PRESS.

Internet www.anr.gov.pl. 04.02.2013.

Internet www.arimr.gov.pl 02.02.2013.

Internet www.deloitte. 05.02.2013.

Internet www.egospodarka. 04.02.2013.

Internet www.epp.eurostat.ec.europa.eu. 02.02.2013.

Inwestowanie na rynku nieruchomości (Investing on a real estate market), Ed. H. Henzel. 2004., Publishing house: WYDAWNICTWO AKADEMII EKONOMICZNEJ W KATOWICACH, p. 82.

\footnotetext{
${ }^{6}$ From the authors' research it turns out that a $10 \%$ annual return rate is an acceptable level of profitability for the majority of investors. However, investors and entrepreneurs on the real estate market need to bear in mind the demands made by protesting farmers from the West Pomeranian voivodeship, who hope to introduce significant limitations concerning land sales by the APA.
} 
KOLIBSKI M. 2012, Spótka komandytowa i komandytowo - akcyjna, praktyczne korzyści podatkowe i prawne oraz optymalizacja podatkowa ich wspólników (Limited partnership and limited joint-stock company), conference materials from the conference "Spótka komandytowa i komandytowo - akcyjna"(Limited partnership and limited joint-stock comapny), Rzeczpospolita, Warsaw 26th April 2012.

Ryzyko w działalności inwestycyjnej - aspekty teoretyczne i praktyczne (Risk in investment activity - practical and theoretical aspects), Vol. II, Red. H. Henzel. 2009., Publishing house: WYDAWNICTWO AKADEMII EKONOMICZNEJ W KATOWICACH, pp. 59-65.

An Act from 15th September 2000, Commercial Companies Code (Dz.U. 2000, No. 94, item 1037). 